\title{
ANALISIS KINERJA PENURUNAN DEFORESTASI DI 10 IZIN HUTAN DESA KECAMATAN BATU AMPAR
}

\author{
(Village Forest Management Strategy to Reduce deforestation for ten village forest licenses \\ holder in Batu Ampar, Kubu Raya)
}

\author{
Denni Nurdwiansyah, Gusti Hardiansyah, Emi Roslinda
}

Fakultas Kehutanan Universitas Tanjungpura, Jalan Imam Bonjol Pontianak, Indonesia e-mail: denni@bentangkalimantan.org

\begin{abstract}
The effectiveness of devolution policies through social forestry programs in village forest schemes is still being debated at regional, national, and international levels. It departs from the fact that the community has limited resources in managing forests in the long run (35 years). The background of this research is to measure the implementation of devolution policy in 10 granted village forest licenses in the sub-district of Batu Ampar, Kubu Raya District, and its relationship with deforestation rates. The study was conducted by survey method and data collection with literature studies and observations. Observation aims to measure the biophysical condition of the forest as well as the social and economic conditions of the community in the village. The data is processed and analyzed using spatial analysis and performance analysis. The results showed that the devolution policy through the issuance of 10 village forest licenses was proven to be able to improve performance in reducing deforestation, especially after one year of the village forest permits were granted.
\end{abstract}

Keywords: devolution, social forestry, village forest, deforestation, performance

Abstrak

Efektifitas kebijakan devolusi melalui program perhutanan sosial skema hutan desa masih menjadi perdebatan di level regional, nasional, dan internasional. Hal ini berangkat dari fakta keterbatasan sumber daya yang dimiliki masyarakat dalam mengelola hutan dalam jangka waktu panjang (35 tahun). Penelitian bertujuan untuk mengurai implementasi kebijakan devolusi di 10 izin hutan desa Kecamatan Batu Ampar, Kabupaten Kubu Raya, dan pengaruhnya terhadap laju deforestasi. Penelitian dilakukan dengan metode survei. Pengumpulan data dengan studi literatur dan observasi. Observasi bertujuan untuk mengetahui kondisi biofisik hutan serta kondisi sosial dan ekonomi masyarakat di desa. Data-data diolah dan dianalisis menggunakan analisis spasial dan analisis kinerja. Hasil penelitian menunjukan kebijakan devolusi melalui pemberian 10 izin hutan desa telah terbukti secara kumulatif mampu meningkatkan kinerja positif dalam penurunan deforestasi, terutama setelah satu tahun izin hutan desa diberikan.

Kata kunci: devolusi, perhutanan sosial, hutan desa, deforestasi, kinerja

\section{PENDAHULUAN}

Paradoks potensi sumber daya yang berlimpah dengan angka kemiskinan, laju deforestasi, dan ketidakadilan distribusi direspons melalui kebijakan devolusi (Suhartijo dan Purwawangsa, 2014). Devolusi lahir dari kesadaran terbatasnya kemampuan negara untuk mengelola sumber daya alam secara efektif, khususnya di tingkat lokal (Khan dkk, 2013). Devolusi diharapkan memberikan keadilan dalam distribusi penguasaan hutan (Suharjito, 2014), dan untuk mempromosikan keadilan sosial (Royer dkk, 2018). Kebijakan devolusi di Indonesia dimulai pada tahun 1995 dengan lahirnya skema hutan kemasyarakatan. Kebijakan ini berkembang melalui 
program perhutanan sosial dengan lima skema, salah satunya skema hutan desa.

Efektifitas implementasi kebijakan devolusi masih menjadi perdebatan di berbagai level. Transfer kekuasaan dan wewenang, dalam banyak kasus, sebenarnya tidak terjadi sebagaimana diatur dalam kebijakan dan undang-undang (Ribot, 2002). Kebijakan devolusi menghadapi berbagai persoalan seperti regulasi yang berat dan kondisi birokrasi yang tidak efektif (Cronkletona dkk, 2012). Upaya menuju devolusi belum optimal dan malah terjadi kemunduran (Anderson, 2000). Devolusi yang fokus terhadap upaya meningkatkan kesejahteraan petani miskin dalam praktiknya tidak berjalan semestinya (Edmunds dan Wollenberg, 2001).

Penelitian bertujuan menguraikan pengaruh kebijakan devolusi dalam program perhutanan sosial terhadap pemberian hutan desa terhadap penurunan laju deforestasi. Izin hutan desa di 10 desa Kecamatan Batu Ampar, Kabupaten Kubu Raya terpilih sebagai objek penelitian.

METODE PENELITIAN

\section{Waktu dan Tempat Penelitian}

Penelitian dilaksanakan sejak bulan Oktober hingga November 2019 di Kecamatan Batu Ampar. Alat penelitian berupa peta lokasi, kamera, alat tulis, dan GPS. Bahan penelitian meliputi data shapefile (shp) deforestasi FREL Kalimantan Barat; shp kinerja penurunan emisi gas rumah kaca Kalimantan Barat; shp penutupan lahan KLHK; shp monitoring deforestasi Sampan Kalimantan; dan shp 10 izin hutan desa di Kecamatan Baru Ampar.

Objek penelitian adalah hutan di 10 izin hutan desa yang ditetapkan pada 12
Februari 2017. Kesepuluh hutan desa memiliki luas 76.370 hektar. Status dan fungsi kawasan di berupa hutan lindung 90,7 persen, hutan produksi terbatas 2,6 persen, dan hutan produksi konversi 6,7 persen.

\section{Metode dan Teknik Pengumpulan Data}

Pengumpulan data dilakukan dengan studi literatur dan survei. Survei melalui observasi dengan melakukan kunjungan lapangan untuk mengetahui kondisi biofisik hutan serta kondisi sosial dan ekonomi masyarakat.

Variabel yang diamati yaitu deforestasi, faktor penyebab deforestasi, dan kinerja penurunan deforestasi di 10 izin hutan desa. Mengacu pada Hardiansyah dkk (2014), deforestasi setidaknya diakibatkan oleh beberapa faktor di beberapa sektor, seperti:

1. Sektor gambut, meliputi kegiatan pembuatan kanal di gambut serta kebakaran hutan dan lahan

2. Sektor pertanian, meliputi kegiatan pemanfaatan lahan berhutan untuk pertanian dan ekstensifikasi kemandirian pangan

3. Sektor kehutanan, meliputi kegiatan luas wilayah desa di sekitar kawasan hutan, perambahan hutan/illegal logging, dan konversi hutan alam untuk penggunaan di luar kehutanan

4. Sektor perkebunan, meliputi kegiatan konversi hutan untuk lahan perkebunan

5. Sektor pertambangan, meliputi kegiatan penambangan emas tanpa izin dan pinjam pakai kawasan hutan untuk pertambangan bauksit

6. Lain-lain, meliputi kegiatan pengembangan infrastruktur jalan di kawasan perbatasan, pengembangan 
ekonomi wilayah, dan pemekaran wilayah Kabupaten/Kota

\section{Pengolahan Data}

Data shp dan hasil obervasi lapangan diolah dengan ArcGIS v10.2 dengan melakukan kluster data sesuai periode waktu (periode 2016-2017, 2017-2018, dan 2018-2019), melakukan tumpang susun (overlay), union sesuai periode analisis, dan membuat tabulasi sesuai dengan tahun yang dianalisis.

\section{Analisa Data}

Data dianalisis menggunakan 2 (dua) instrumen analisis, yaitu: (1) Analisis spasial, untuk melihat deforestasi dan faktor penyebab setelah pemberian izin hutan desa di 10 desa, dan (2) Analisis kinerja, untuk melihat kinerja penurunan deforestasi setelah pemberian izin.

Periode yang dianalisis yaitu periode 2016-2017, 2017-2018, dan 2018-2019. Indikator analisis kinerja adalah peningkatan (kinerja negatif) atau pengurangan (kinerja positif) deforestasi dari ambang batas (baseline) deforestasi tahunan.

Pengertian deforestasi yang digunakan dalam penelitian ini merujuk pada perhitungan deforestasi dalam kerangka Reducing Emission from Deforestation and Degradation (REDD). Mengacu pada Peraturan Menteri kehutanan Nomor 30 tahun 2009 tentang Tata Cara Pengurangan Emisi dari Deforestasi dan Degradasi Hutan (REDD), deforestasi didefinisikan sebagai perubahan secara permanen dari areal berhutan menjadi tidak berhutan yang diakibatkan kegiatan manusia dan hanya terjadi satu kali.

\section{HASIL DAN PEMBAHASAN}

\section{Deforestasi di 10 Izin Hutan Desa}

Deforestasi setelah pemberian izin hutan desa yaitu pada periode 2016-2017, 2017-2018, dan 2018-2019 terjadi seluas 2.974 hektar sebagaimana tersaji dalam Tabel 1. Seluruh desa mengalami deforestasi setelah satu tahun izin hutan desa terbit pada periode 2016-2017 dan terjadi penurunan pada periode berikutnya yaitu periode 2017-2018 dan 2018-2019. Masyarakat di Desa Medan Mas, Desa Padang Tikar 1, Desa Tasik Malaya, dan Desa Teluk Nibung mampu mempertahankan tren penurunan deforestasi sebesar nol hektar setelah satu tahun izin hutan desa.

Tabel 1. Deforestasi Berdasarkan Wilayah Administrasi Izin Hutan Desa (Deforestation Based on Administrative Areas of Village Forest Permits)

\begin{tabular}{clcccc}
\hline \multirow{2}{*}{ No. } & \multirow{2}{*}{ Nama Desa } & $\mathbf{2 0 1 6 - 2 0 1 7}$ (ha) & $\begin{array}{c}\text { Periode } \\
\mathbf{2 0 1 7 - 2 0 1 8}(\mathbf{h a})\end{array}$ & $\mathbf{2 0 1 8 - 2 0 1 9}$ (ha) & Total (ha) \\
\hline 1 & Ambarawa & 275 & - & 21 & 297 \\
2 & Batu Ampar & 403 & 277 & 62 & 742 \\
3 & Medan Mas & 48 & - & - & 48 \\
4 & Nipah Panjang & 158 & - & 13 & 172 \\
5 & Padang Tikar 1 & 3 & - & - & 3 \\
6 & Sungai Besar & 495 & - & 2 & 496 \\
7 & Sungai Jawi & 250 & - & 2 & 252 \\
8 & Tanjung Harapan & 223 & 4 & 100 & 327 \\
9 & Tasik Malaya & 626 & - & - & 626 \\
10 & Teluk Nibung & 12 & - & - & 12 \\
\hline \multicolumn{7}{r}{ Total } & $\mathbf{2 . 4 9 3}$ & $\mathbf{2 8 1}$ & $\mathbf{2 0 0}$ & $\mathbf{2 . 9 7 4}$ \\
\hline
\end{tabular}

Sumber: Penelitian tahun 2019 
Hasil analisa deforestasi sebagaimana Tabel 1 di atas kemudian dilakukan observasi dan pengecekan di lapangan terkait faktor penyebab terjadi deforestasi. Identifikasi faktor penyebab deforestasi hanya dapat dilakukan pada periode 2017-2018 dan 2018-2019. Identifikasi faktor penyebab deforestasi untuk periode 2016-2017 tidak dapat dikumpulkan secara menyeluruh dikarenakan data dan informasi di lapangan yang kurang memadai dari masyarakat. Penelitian menggunakan analisis faktor penyebab deforestasi dalam kerangka REDD+, sebagaimana disadur dalam Hardiansyah dkk (2014).

Tabel 2. Faktor Penyebab Deforestasi Periode 2017-2018 dan 2018-2019 (The Underlying Causes of Deforestation for the 2017-2018 and 2018-2019 periods)

\begin{tabular}{|c|c|c|c|c|c|c|}
\hline \multirow{3}{*}{ No } & \multirow{3}{*}{ Nama Desa } & \multicolumn{4}{|c|}{ Periode (ha) } & \multirow{3}{*}{$\begin{array}{c}\text { Total } \\
\text { (ha) }\end{array}$} \\
\hline & & \multicolumn{2}{|c|}{ 2017-2018 } & \multicolumn{2}{|c|}{ 2018-2019 } & \\
\hline & & $\begin{array}{c}\text { Illegal } \\
\text { Logging }\end{array}$ & Karhutla & $\begin{array}{c}\text { Illegal } \\
\text { Logging }\end{array}$ & Karhutla & \\
\hline 1 & Ambarawa & - & - & - & 21 & 21 \\
\hline 2 & Batu Ampar & 277 & - & 7 & 54 & 339 \\
\hline 3 & Medan Mas & - & - & - & - & - \\
\hline 4 & Nipah Paniang & - & - & - & 13 & 13 \\
\hline 5 & Padang Tikar 1 & - & - & - & - & - \\
\hline 6 & Sungai Besar & - & - & 2 & - & 2 \\
\hline 7 & Sungai Jawi & - & - & 2 & - & 2 \\
\hline 8 & $\begin{array}{l}\text { Tanjung } \\
\text { Harapan }\end{array}$ & 4 & - & - & 100 & 103 \\
\hline 9 & Tasik Malava & - & - & - & - & - \\
\hline 10 & Teluk Nibung & - & - & - & - & - \\
\hline & Total & 281 & - & 11 & 189 & 481 \\
\hline
\end{tabular}

Sumber: Penelitian tahun 2019

Mengacu hasil analisis sebagaimana tersaji dalam Tabel 2 di atas, faktor penyebab deforestasi periode 2017-2018 dan 2018-2019 disebabkan dua faktor utama, yaitu perambahan hutan (illegal logging) dan kebakaran hutan. Praktik perambahan hutan masih menjadi faktor dominan. Deforestasi akibat perambahan hutan periode 2017-2018 dan 2018-2019 seluas 292 hektar, berkontribusi sebesar 61 persen dari deforestasi di dua periode tersebut. Deforestasi akibat kebakaran hutan dan lahan (karhutla) berkontribusi sebesar 39 persen. 


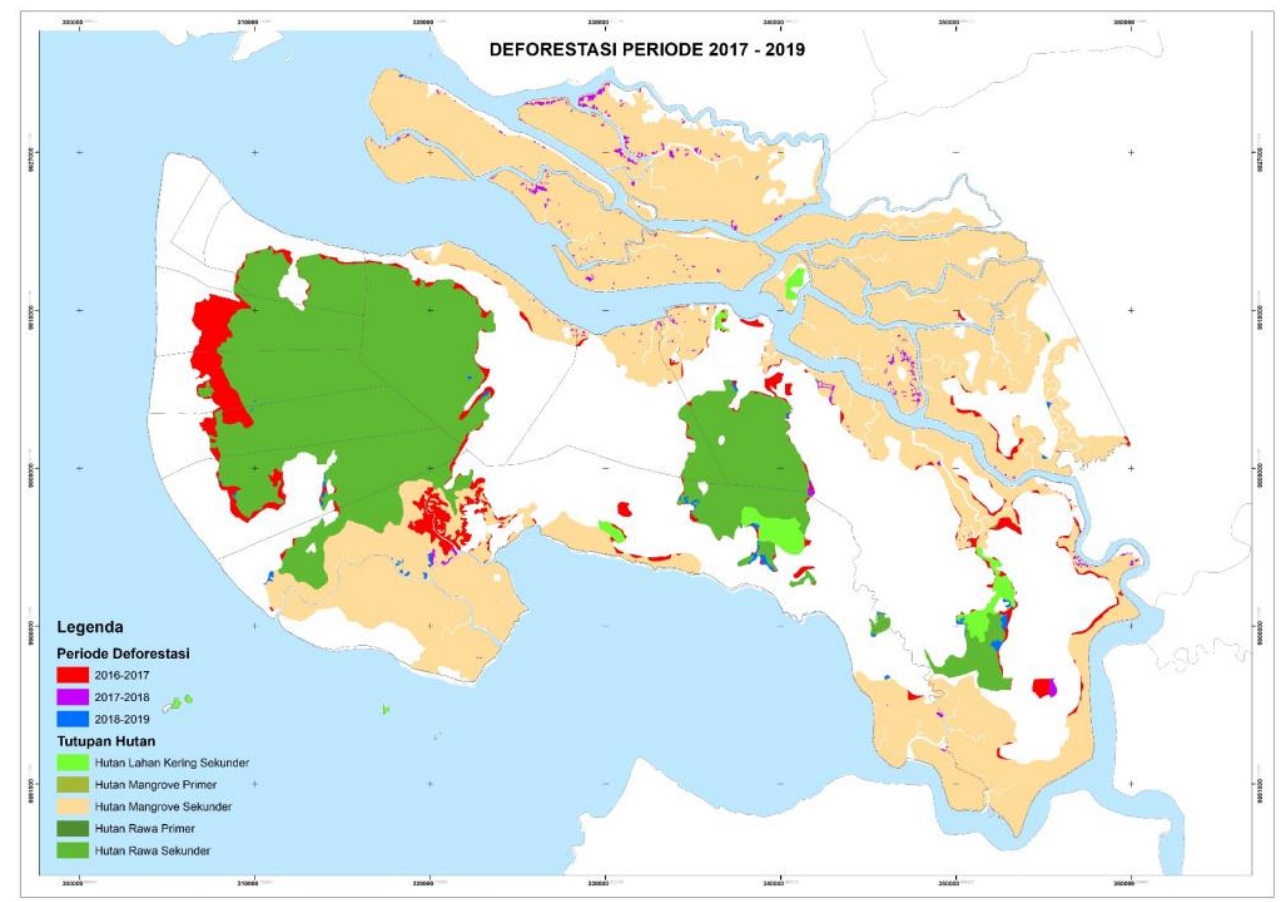

Gambar 1. Peta Deforestasi Periode 2016-2017, 2017-2018, dan 2018-2019

(Deforestation Map for 2016-2017, 2017-2018, and 2018-2019 Periods)

Mengacu pada Gambar 1 diatas, deforestasi akibat perambahan hutan di Desa Batu Ampar dan Desa Tanjung Harapan pada periode 2017-2018 terjadi pada tipe hutan mangrove. Deforestasi kembali terjadi di Desa Batu Ampar pada periode 2018-2019. Deforestasi di kedua desa tersebut memiliki tujuan berbeda.

Deforestasi di Desa Batu Ampar dominan disebabkan usaha tradisional dapur arang masyarakat dengan areal tebangan berada di hutan lindung dalam izin hutan desa. Jenis kayu yang paling banyak digunakan masyarakat untuk arang bakau seperti Bakau Lumut (Rhizophora apiculata), Bakau Blukup (Rhizophora mucronata), dan Bakau Tembaga (Rhizophora Stylosa).

Produk olahan berupa arang bakau dengan tujuan pasar ekspor. Deforestasi di Desa Tanjung Harapan disebabkan perambahan untuk kebutuhan kayu komersial. Produk berupa kayu gergajian dengan tujuan pasar lokal dan luar kecamatan.

Praktik usaha tradisional arang di Desa Batu Ampar telah berjalan sejak tahun 1906, dan jumlah dapur arang pada tahun 2015 tercatat telah melebihi 400 unit (Ritabulan dkk, 2016). Usaha arang tradisional menjadi topangan ekonomi 3040 persen penduduk desa. Jumlah tersebut berpotensi bertambah dengan tingginya permintaan arang dari pasar nasional maupun internasional, serta jika tidak insentif kebijakan maupun penciptaan alternatif ekonomi baru.

Perambahan di izin hutan desa lain mengacu pada Gambar 1 berada di hutan rawa gambut. Sumber kayu untuk pemenuhan kayu keseluruhannya hanya berada pada hutan rawa gambut di hutan lindung dalam izin hutan desa. Jenis kayu di hutan rawa gambut yang paling banyak 
dimanfaatkan mayoritas berasal dari Genus Meranti (Shorea sp.), seperti Meranti Batu (Shorea platyclados). Produk kayu berupa kayu gergajian dengan tujuan pasar berada di desa-desa dalam kecamatan. Hasil kayu gergajian mayoritas digunakan untuk pemenuhan bahan baku kayu untuk perumahan, perabotan rumah tangga, infrastruktur sosial (jalan, jembatan, dan fasilitas umum), serta perluasan areal pemukiman.

Perambahan di hutan mangrove dan hutan rawa gambut pada hutan lindung yang berada di dalam izin hutan desa disebabkan beberapa faktor, antara lain:

1. Kegiatan perambahan hutan adalah alternatif pekerjaan yang sangat efektif menurut para penebang untuk mendapatkan penghasilan yang tinggi dalam waktu yang singkat.

2. Minimnya teknologi untuk meningkatkan produksi hasil pertanian dan perkebunan serta nilai tambah dari diversifikasi produksi. Ekspansi lahan menjadi strategi utama dalam meningkatkan produktivitas lahan. Hal ini berlaku di semua desa dan terjadi di semua tipe hutan.

3. Permintaan pasar terhadap produk kayu yang masih tinggi baik untuk arang bakau dari hutan mangrove, maupun kayu gergajian dari hutan rawa gambut.

4. Pengembangan alternatif ekonomi dari sektor hasil hutan non-kayu dan jasa lingkungan belum sepenuhnya berkembang baik yang difasilitasi lembaga pendamping dan pemerintah dan menjangkau masyarakat yang sepenuhnya bergantung pada nilai ekonomi kayu
5. Ekspansi pemukiman. Pemukiman dan wilayah kelola umumnya berbatasan langsung dengan hutan rawa gambut.

6. Kurangnya pengawasan dan penegakan hukum bagi pelaku perambahan hutan.

Hal tersebut sebagaimana dikatakan Ali dkk (2018) bahwa terdapat 5 faktor yang menyebabkan terjadinya perambahan hutan, khususnya yang terjadi di Desa Lunyuk Ode, Kabupaten Sumbawa Besar. Adapun faktor tersebut berkaitan dengan rendahnya pendapatan masyarakat, kurangnya lapangan pekerjaan, pendidikan rendah, masih lemahnya penjagaan hutan, keringanan hukum bagi pelaku perambahan hutan, dan banyaknya permintaan akan kayu. Dhaka dkk (2017) juga menegaskan bahwa terdapat 5 faktor yang menyebabkan terjadinya perambahan yaitu faktor ekonomi, faktor pendidikan, adanya sponsor, keterbatasan petugas pengawas hutan, dan lemahnya sanksi hukum kepada pelaku.

Dalam konteks pengelolaan 10 izin hutan desa, faktor yang menyebabkan masih terjadinya perambahan hutan sebagai berikut:

1. Luasnya areal izin dan sumber daya finansial yang terbatas membuat tata batas areal izin hutan desa di 10 desa belum dilakukan oleh Lembaga Pengelola Hutan Desa (LPHD).

2. Upaya penataan usaha hasil hutan kayu di hutan produksi masih belum menjadi prioritas program (LPHD) di 10 desa, khususnya desa dengan potensi hutan produksi. Hal ini berdasarkan pandangan masyarakat bahwa tutupan hutan yang berada di izin 10 desa masih luas, termasuk yang berada di hutan lindung. 
3. Jumlah dan intensitas perambahan hutan sulit dihilangkan, jika tidak ada pengembangan usaha kayu areal hutan produksi di dalam izin hutan desa, maupun di luar izin hutan desa.

Mengacu pada Tabel 2, meskipun deforestasi akibat perambahan masih terjadi, namun mengalami tren penurunan. Penurunan disebabkan beberapa faktor, di antaranya:

1. Sebagian wilayah tebang masyarakat beralih ke areal berhutan di luar izin hutan desa, baik di areal non-izin dan konsesi perusahaan.

2. Perkembangan alternatif pendapatan masyarakat di sektor hasil hutan non kayu, jasa lingkungan, maupun optimalisasi dan intensifikasi disektor perkebunan, pertanian, dan perikanan. Penciptaan alternatif cukup insentif dilakukan dengan tingkat keberhasilan dan kegagalan bervariasi. Skema pembiayaan berkembang ke arah skema kredit lunak (tidak melalui skema hibah), melalui program link and match dengan beberapa instansi keuangan pemerintah dan swasta. Sebagai contoh, Desa Batu Ampar untuk komoditas kepiting dan Desa Nipah Panjang komoditas madu. Skema ini menuntut masyarakat untuk serius dalam pengembangan sehingga terjadi peralihan fokus terhadap aktivitas.

3. Sistim penebangan. Khusus di Desa Batu Ampar, sistim silvikultur yang digunakan menggunakan sistim tebang rumpang dengan penebangan areal seluas $\pm 0,5$ hektar (Mulia, 2009). Hal tersebut juga berlaku untuk desa lain. Kondisi tegakan hutan berada dalam kondisi yang bervariasi sehingga area tebang masyarakat berdasarkan hasil observasi berada di bawah 0,25 hektar. Bekas areal tebang tersebut dalam kerangka REDD+ dikategorikan sebagai degradasi.

4. Wilayah tebang masyarakat yang berada di hutan lindung di dalam areal izin hutan desa telah terdeforestasi sebelumnya. Sehingga wilayah tersebut tidak dapat dikategorikan sebagai areal terdeforestasi, tetapi degradasi. Hal ini berdasarkan penggunaan definisi deforestas dalam penelitian ini yaitu perubahan secara permanen dari areal berhutan menjadi tidak berhutan yang diakibatkan kegiatan manusia dan hanya terjadi satu kali.

Penggunaan kerangka REDD+ dalam penelitian ini tidak dapat secara detail menggambarkan kondisi penebangan hutan di lapangan. Hasil penelitian ini dapat dijadikan ukuran makro guna menyusun rekomendasi aksi pengelolaan hutan desa ke depan. Upaya pencegahan perambahan hutan harus tetap berlanjut di tingkat lapangan, meskipun tren deforestasi menurun dan beberapa desa terdapat nol deforestasi. Hal ini mengingat kondisi sosial dan ekonomi dinamis dan berkembang setiap saat.

Ada beberapa faktor sehingga penggunaan kerangka ini tidak dapat secara detail menggambarkan kondisi lapangan, antara lain:

1. Definisi deforestasi dalam penelitian ini yaitu perubahan secara permanen dari areal berhutan menjadi tidak berhutan yang diakibatkan kegiatan manusia dan hanya terjadi satu kali dengan luas $\geqslant$ 0,25 hektar. Meskipun terdapat desa dengan luas deforestasi nol, tetapi secara 
faktual aktivitas penebangan hutan masih dapat terlihat secara jelas. Kerusakan hutan yang terjadi akibat penebangan hutan jika $\leqslant 0,25$ hektar diklasifikasikan sebagai degradasi.

2. Penebangan di areal suksesi atau reforestasi meskipun tegakan hutan telah membentuk hutan sekunder tidak terhitung sebagai deforestasi karena deforestasi telah dihitung pada periode sebelumnya.

Deforestasi akibat perambahan hutan di hutan desa menjadi salah satu tantangan terberat bagi 10 pemegang izin hutan desa di Kecamatan Batu Ampar. Hal ini dikarenakan, beberapa model pengelolaan hutan di mana masyarakat dijadikan aktor utama justru berdampak nyata pada kerusakan hutan, seperti:

1. Program HKM di Lombok menyebabkan kerusakan ekologi sumber daya hutan (Dipokusumo, 2011).

2. Program JFM (Joint Forest Management) di India menyebabkan degradasi lahan sebesar $42 \%$ dari luas hutan 633.400 hektar (Khare dkk, 2000).

3. Program community forest di Kameron tidak dikelola secara berkelanjutan (Brown dan Lassoie, 2010).

4. Community forest management di Madagaskar gagal menurunkan deforestasi dibandingkan model lain (Rasolofoson dkk, 2015).

Kegagalan pada pengelolaan Program JFM (Joint Forest Management) di India, community forest di Kameron, dan community forest management $\mathrm{di}$ Madagaskar juga disebabkan ketidakmampuan dalam menurunkan kasus perambahan hutan yang terjadi baik yang dilakukan masyarakat desa maupun dari luar desa.

Tantangan lain adalah kebakaran hutan. Sebagaimana Tabel 2, deforestasi akibat kebakaran hutan mencapai 189 hektar yang terjadi di hutan rawa gambut. Menurut Santika dkk (2017), hutan desa terbukti dapat mengurangi deforestasi di Kalimantan dan Sumatera, namun tantangan terberat penurunan deforestasi di hutan desa adalah kondisi iklim dan cuaca.

Santika dkk (2017) menambahkan jumlah curah hujan selama musim kemarau secara signifikan mengurangi kinerja dalam mengurangi deforestasi, terutama yang berlokasi di lahan gambut, di mana daerah sekitarnya sudah terdegradasi dan kebakaran berulang terjadi, sehingga sangat rentan terjadi kebakaran hutan.

Pola kebakaran hutan di yang terjadi di ke 10 izin hutan desa relatif sama. Kebakaran terjadi berulang-ulang di lokasi yang sama, pasca kebakaran tahun 2015. Faktor penyebab kebakaran pun relatif sama, yaitu pembukaan lahan dengan bakar yang masih diaplikasikan masyarakat. Upaya pencegahan sudah berjalan, seperti melakukan penanaman di areal bekas kebakaran, pembangunan sekat kanal dan sumur bor, serta penegakan hukum. Upaya pencegahan juga telah dibarengi dengan peningkatan kapasitas dan infrastruktur pengendalian kebakaran hutan.

Pencegahan dalam aspek perubahan paradigma dan transfer teknologi belum banyak dilakukan, sehingga praktik pembukaan lahan dengan membakar sesungguhnya masih terjadi dilapangan. Kondisi infrastruktur pengendalian kebakaran hutan juga belum maksimal, 
mengingat luasnya areal hutan desa dan akses yang sulit. Optimalisasi upaya pencegahan dan pengendalian harus menjadi prioritas program hutan desa ke depan. Santika (2017) memperkuat optimalisasi upaya pencegahan dan penanggulangan, peningkatan kapasitas teknis, dan asistensi keuangan diperlukan agar kasus kebakaran dapat ditekan.

\section{Kinerja Penurunan Deforestasi di 10 Izin Hutan Desa}

Kinerja penurunan deforestasi diukur berdasarkan adanya peningkatan (kinerja negatif) atau pengurangan (kinerja positif) deforestasi dari ambang batas (baseline) deforestasi tahunan. Pengukuran kinerja merupakan pendekatan dalam REDD+ untuk melihat keberhasilan atau kegagalan dalam penurunan emisi dari deforestasi dan degradasi hutan pada tahun-tahun tertentu. Ambang batas deforestasi diukur dari rerata deforestasi yang terjadi sebelum izin hutan desa terbit, yaitu periode 1990-1996, 19962000, 2000-2003, 2003-2006, 2006-2009, 2009-2011, 2011-2012, 2012-2013, 20132014, 2014-2015, dan 2015-2016. Ambang batas deforestasi tahunan secara keseluruhan di 10 izin hutan desa sebesar 1.148 ha per tahun.

Mengacu pada Tabel 3 di bawah, setelah pemberian izin hutan desa, kinerja penurunan deforestasi secara keseluruhan di 10 izin hutan desa pada periode 20162017 memperoleh kinerja negatif sebesar 117 persen dari angka ambang batas deforestasi. Kinerja penurunan deforestasi baru mengalami penurunan pada periode 2017-2018 sebesar 76 persen dan periode 2018-2019 sebesar 83 persen dari ambang batas deforestasi tahunan di izin hutan desa. Kinerja penurunan deforestasi sebagaimana tabel di bawah ini:

Tabel 3. Kinerja Penurunan Deforestasi di 10 izin Hutan Desa (Deforestation Reduction Performance in 10 Village Forest licenses)

\begin{tabular}{|c|c|c|c|c|c|c|c|c|c|c|c|}
\hline \multirow[b]{2}{*}{ Periode } & \multirow[b]{2}{*}{$\begin{array}{c}\text { Ambar } \\
\text { awa }\end{array}$} & \multirow[b]{2}{*}{$\begin{array}{c}\text { Batu } \\
\text { Ampar }\end{array}$} & \multirow[b]{2}{*}{ Medan Mas } & \multirow[b]{2}{*}{$\begin{array}{c}\text { Nipah } \\
\text { Panjang }\end{array}$} & \multicolumn{2}{|c|}{ Desa (ha) } & \multirow[b]{2}{*}{$\begin{array}{c}\text { Sungai } \\
\text { Jawi }\end{array}$} & \multirow[b]{2}{*}{$\begin{array}{l}\text { Tanjung } \\
\text { Harapan }\end{array}$} & \multirow[b]{2}{*}{$\begin{array}{c}\text { Tasik } \\
\text { Malaya }\end{array}$} & \multirow[b]{2}{*}{$\begin{array}{c}\text { Teluk } \\
\text { Nibung }\end{array}$} & \multirow[b]{2}{*}{ Total } \\
\hline & & & & & $\begin{array}{l}\text { Padang } \\
\text { Tikar } 1 \\
\end{array}$ & $\begin{array}{c}\text { Sungai } \\
\text { Besar }\end{array}$ & & & & & \\
\hline 2016-2017 & 275 & 403 & 48 & 158 & 3 & 495 & 250 & 223 & 626 & 12 & 2.493 \\
\hline Ambang Batas (ha) & 35 & 684 & 31 & 37 & 4 & 5 & 5 & 306 & 8 & 33 & 1.148 \\
\hline Kinerja -/+ (ha) & -240 & 282 & -17 & -122 & 1 & -490 & -245 & 83 & -618 & 20 & -1.345 \\
\hline Kinerja $-/+(\%)$ & -678 & 41 & -55 & -331 & 33 & -10.563 & -4.608 & 27 & -7.394 & 63 & -117 \\
\hline $2017-2018$ & 0 & 278 & 0 & 0 & 0 & 0 & 0 & 4 & 0 & 0 & 281 \\
\hline Ambang Batas (ha) & 35 & 684 & 31 & 37 & 4 & 5 & 5 & 306 & 8 & 33 & 1.148 \\
\hline Kinerja -/+ (ha) & 35 & 406 & 31 & 37 & 4 & 5 & 5 & 302 & 8 & 33 & 867 \\
\hline Kinerja $-/+(\%)$ & 100 & 59 & 100 & 100 & 100 & 100 & 100 & 99 & 100 & 100 & 76 \\
\hline 2018-2019 & 21 & 62 & 0 & 13 & 0 & 2 & 2 & 100 & 0 & 0 & 200 \\
\hline Ambang Batas (ha) & 35 & 684 & 31 & 37 & 4 & 5 & 5 & 306 & 8 & 33 & 1.148 \\
\hline Kinerja -/+ (ha) & 14 & 622 & 31 & 24 & 4 & 3 & 3 & 206 & 8 & 33 & 949 \\
\hline Kinerja $-/+(\%)$ & 39 & 91 & 100 & 64 & 100 & 61 & 65 & 67 & 100 & 100 & 83 \\
\hline Kumulatif Deforestasi & 297 & 742 & 48 & 172 & 3 & 496 & 252 & 327 & 626 & 12 & 2.974 \\
\hline Kumulatif Kinerja (ha) & -191 & 1.310 & 45 & -61 & 10 & -482 & -236 & 591 & -601 & 86 & 471 \\
\hline
\end{tabular}

Sumber: Penelitian tahun 2019

Kebijakan devolusi melalui pemberian 10 izin hutan desa di 10 desa telah terbukti mampu meningkatkan kinerja penurunan laju deforestasi. Meskipun deforestasi masih terjadi, namun kinerja penurunan deforestasi secara konsisten memperoleh kinerja positif setelah satu tahun izin hutan desa terbit. Hal ini sebagaimana Samii dkk. (2014) bahwa program decentralization forest management yang dijalankan di beberapa negara berhasil mengurangi 
rata-rata tingkat deforestasi meskipun dalam jumlah yang tidak signifikan. Shi (2016) mengatakan pengelolaan hutan berbasis masyarakat memiliki tingkat deforestasi yang kecil dibandingkan model lain dalam situasi-situasi tertentu. Selain itu, kebijakan devolusi dalam program Community Based Woodfuel Production (CBWP) di Nepal dan Senegal terbukti berhasil merehabilitasi hutan dan mengurangi rata-rata laju deforestasi (Behrendt dkk, 2013).

\section{KESIMPULAN}

Deforestasi setelah pemberian izin hutan desa terjadi seluas 2.974 hektar yang diakibatkan 2 (dua) faktor utama yaitu perambahan hutan (illegal logging) dan kebakaran hutan. Seluruh desa mengalami deforestasi setelah satu tahun izin hutan desa terbit pada periode 20162017 dan terjadi penurunan pada periode berikutnya yaitu periode 2017-2018 dan 2018-2019. Kebijakan devolusi melalui pemberian 10 izin hutan desa telah terbukti mampu menurunkan laju deforestasi.

\section{SARAN}

1. Tata kelola pemanfaatan kayu harus diatur secara komprehensif oleh LPHD di 10 desa sehingga tidak menyebabkan deforestasi di hutan lindung, khususnya dari perambahan hutan, melalui pemanfaatan hutan produksi di hutan desa maupun pengembangan usaha kayu di luar hutan desa

2. Optimalisasi lahan di luar kawasan 10 izin hutan desa perlu dilakukan untuk sektor perkebunan dan pertanian sehingga tidak merambah hutan lindung.
3. Upaya pencegahan dan penanganan kebakaran harus menjadi bagian penting dari pengelolaan hutan desa dan dibarengi dengan peningkatan kapasitas masyarakat serta infrastruktur yang memadai.

DAFTAR PUSTAKA

Anderson J. 2000. Four Considerations for Decentralised Forest Management: Subsidiarity, Empowerment, Pluralism and Social Capital. RECOFTC Report. Bangkok: FAO and RECOFTC

Behrendt H, Megevand C, Sander K. 2013. Deforestation Trends in the Congo Basin. The World Bank

Brown CP, Lassoie JP. 2010. Institutional Choice and Local Legitimacy in Community-Based Forest Management: Lessons from Cameroon. Environmental Conservation 37 (3): 261-269

Dhaka YR, Leksono A, Suprayitno D. 2017. Analisis dan Dampaknya Secara Ekonomi, Ekologi dan Faktor yang Mempengaruhi Perambahan Hutan di Kawasan Cagar Alam Watu Ata Kecamatan Bajawa. Jurnal Konservasi Sumberdaya Hutan Jurnal Ilmu Kehutanan. 1 (4): 51-58

Dipokusumo B. 2011. Model Partisipatif Perhutanan Sosial Menuju Pengelolaan Hutan Berkelanjutan. Desertasi IPB. Bogor

Cronkletona P, Puhlin MJ, Saigal S. 2012. Co-management in Community Forestry How the Partial Devolution of Management Rights Creates Challenges for Forest Communities. Conservation \& Society. 10 (2): 91-102 
Edmunds D dan Wollenberg E. 2001. Historical Perspectives on Forest Policy Change in Asia: An Introduction. Environmental History, 6(2), 190-212.

Hardiansyah G, Yani, A, Rosadi J, Fahrizal, Yosef LN, Boy M, Aripin, Hendarto, Darmawel, Zuhry H. 2014. Strategi dan Rencana Aksi Provinsi REDD+ Kalbar. Pontianak: UNU Press

Ismail F. 2018. Statistika Untuk Penelitian Pendidikan dan IlmuIlmu Sosial. Jakarta: Prenadamedia Group

Khare A, Sarin M, Saxena S, Palit S, Bthla F, Vania dan Satyanaranayana M. 2000. Joint Forest Management: Policy, Practice and Prospects. United Kingdom: International Institute for Environment and Development.

Khan, Azis, Nugroho B, Suharjito D, Darusrnan D, Zuhud EAM, Hardjanto, Kartodihardjo H, Hendrayanto, Shohibuddin M, Sardjono MA dkk. 2013. Kembali Kejalan LURUS: Kritik Penggunaan IImu dan Praktek Kehutanan Indonesia. Forci Development, Yogyakarta

Muktasam, Bambang D., Bambang HK., Markum, Rosiyadi S. dan Siti H. 2003. Implementasi Agroforestry dan Sistem Usahatani Terpadu. Melalui Partisipasi Masyarakat Daerah Pinggiran Hutan dan Lahan Kering Miring. Mataram. Laporan Penelitian P3P Universitas Mataram

Mulia, F. 2009. Review Sistim Silvikultur Mangrove Batu Ampar, Kalimantan Barat. Jakarta
Rasolofoson RA, Ferraro PJ, Jenkins CN, dan Jones JPG. 2015. Effectiveness of Community Forest Management at Reducing Deforestation in Madagascar. Biological Conservation 184 (2015): 271-277

Ribot JC. 2002. Democratic Decentralisation of Natural Resources: Institutionalising Popular Participation. Cape Town: World Resources Institute

Ritabulan, Basuni S, Santoso N, Bismark M. 2016. Hambatan Implementasi Kebijakan Hutan Tanaman Rakyat di Batu Ampar, Propinsi Kalimantan Barat. Jurnal Analisis Kebijakan 13 (2): 73-84

Royer SD, Noordwijk MV, Roshetko, JM. 2018. Does community-based forest management in Indonesia devolve social justice or social costs?. International Forestry Review: 20 (2):167-180

Santika T, Meijaard E, Budiharta S, Law EA, Kusworo A, Hutabarat JA, Indrawan TP, Struebig M, Raharjo S, Huda I, Sulhani, Ekaputri AD, Trison S, Stigner M, dan Wilson KA. 2017. Global Environmental Change 46 (2017): 60-71

Samii C, Lisiecki M, Kulkarni P, Paler L dan Chavis L. 2014. Effects of Decentralized Forest Management (DFM) on Deforestation and Poverty in Low and Middle Income Countries: A Systematic Review Campbell Systematic Reviews. New York

Shi M, Yin R, Zulu L, Qi J, Freudenberger M, Sommerville M. 2016. Empirical linkages between devolved tenure systems and forest conditions: Selected case studies and country experiences, Forest 
JURNAL TENGKAWANG (2021)

Vol. 11 (1): 59 - 70

Policy and Economics (2016), http://dx.doi.org/10.1016/j.forpol. $\underline{2016.05 .018}$

Suharjito D. 2014. Devolusi Pengelolaan Hutan dan Pembangunan Masyarakat Pedesaan. Institut Pertanian Bogor 